\title{
ABERRANT SILVER MAPLES
}

\author{
Scott S. Pauley and Albert Johnson
}

With one plate

Aberrant forms of the silver maple, Acer saccharinum L., have long been known in Europe and the United States. As early as 1893 Schwerin (1) described five varieties and 23 forms, including most, if not all, of the forms known today. Most of these forms differ from the normal species in shape or color of the leaf, but they include also columnar and pendulous growth habits. Rehder (2) lists the varieties pendulum, pyramidale, lutescens, tripartitum and laciniatum. The last of these varieties includes the cultivated "Skinner" maple and "Wier" maple. The Wier maple has dissected leaves, but the lobes are not abnormally slender, while Skinner's maple has leaves with extremely slender lobes. These extreme forms of the silver maple have been described in the American Nurseryman (3) with an even more extreme form from the Willis Nursery Company of Ottawa, Kansas. The Skinner variety seems to have originated independently in several widely separated areas.

Our experience with silver maple variants began in 1947 when we grafted a very young, apparently normal, seedling on to a normal one-year old seedling. The grafted seedling soon began to show what appeared to be a mosaic infection, with abnormal leaf development and a mottled appearance. Eventually a sucker developed from the rootstock which was normal in every respect even at the end of two-year's growth. Grafts between branches of the scion into shoots from the rootstock showed no apparent transmission of a virus to the normal stock.

In 1950 seed was collected from an isolated atypical silver maple at the Arboretum's Case Estate in Weston, Mass. This tree had abnormal mosaic leaves, but was not nearly as aberrant as some of its seedlings. From approximately one hundred seedlings four distinct types of segregates were obtained. In addition to the normal segregates there was one resembling the variety laciniata, two of which were similar to Wier's maple, and nine similar to Skinner's variety. The latter two types not only had small leaves with narrow lobes, but were also mottled and deficient in chlorophyll. Photographs of the four different types are shown in PLATE 1.

The leaf aberrations in these segregates are correlated with growth habit as is the case in the Wier and Skinner maples. The laciniata type of segregate, with little or no evidence of abnormal chlorophyll development, is perhaps more spreading in growth habit than the normal silver maple and is not as vigorous. The Wier type has somewhat pendulous branches and grows slowly, while the Skinner type of segregate is very spreading in growth habit and is even less vigorous.

In 1950 and again in 1951 buds from several different normal silver maples were budded on these mosaic segregates and in no case was there 
any evidence of mosaic transmission. The budding in 1951 was done in early August, and as soon as the bud had set, the branch above the bud was cut back, to force the growth of the bud. Thus it was possible to get several months growth of the normal branch. The buds inserted in 1950 made a complete season's growth without showing any evidence of mosaic.

The symptoms of these abnormal silver maples certainly suggest virus infection, but the failure to transmit the mosaic by either budding or grafting, and the fact that at least two different mosaic types of segregates were among the progeny of a single tree, throw some doubt on the virus origin of these variants. In the case of prunus virus (3), however, the virus transmission by grafting requires two full seasons of growth (4). It is possible that these aberrant seedlings had a virus which was slow to develop symptoms when transmitted to a normal host.

Blakeslee (5) has found a mutation in Datura which resembles the effect of a virus disease. Both the virus infected and the mutant type showed modified leaves, capsules and flowers. In view of the failure to transmit the mosaic by budding or grafting, and the segregation of four distinct types of progeny from a single parental tree, it appears that the aberrant silver maples described are of genetic origin.

Recently John and Wilson (6) have described a somewhat similar genetically conditioned leaf character in the cucumber, Cucumis sativus L. They found what was termed a "ginkgo leaf" variation to be inherited as a simple Mendelian recessive factor. No variation in degree of expression such as observed in the Acer mutants was reported.

\section{LITERATURE CITED}

1. Schwerin, F. G. Die Varietäten der Gattung Acer. Paul Parey, Berlin. 1893.

2. Rehder, A. Manuel of cultivated trees and shrubs. Macmillan Co. New York. 1940.

3. Anonymous. Weeping Silver Maple. American Nurseryman, 68(8): 13. 1938.

4. Smith, K. Plant Virus Diseases. J. \& A. Churchill, Ltd. London. 1937.

5. Blakeslee, A. F. Growth patterns in plants. Growth Symposium. 1941.

6. John, C. A. \& Wilson, J. D. A "gingko leafed" mutation in the cucumber. Jour. Hered., 43: 47-48. 1952.

\section{DESCRIPTION OF PLATE}

Typical leaves of silver maple segregates from a single parental tree.

1. Leaf of extreme variant similar to those of a variant described by the Willis Nursery Co. The leaves have extremely narrow lobes and have chlorophyll deficiencies characteristic of a virus infection.

2. Leaf of a normal segregate.

3. Leaf of a segregate with small leaves similar to those of "Wierii." These leaves show little or no mosaic characteristics.

4. Leaf of a segregate resembling "Skinners" silver maple. Chlorophyll aberrations resemble those caused by mosaic virus. 


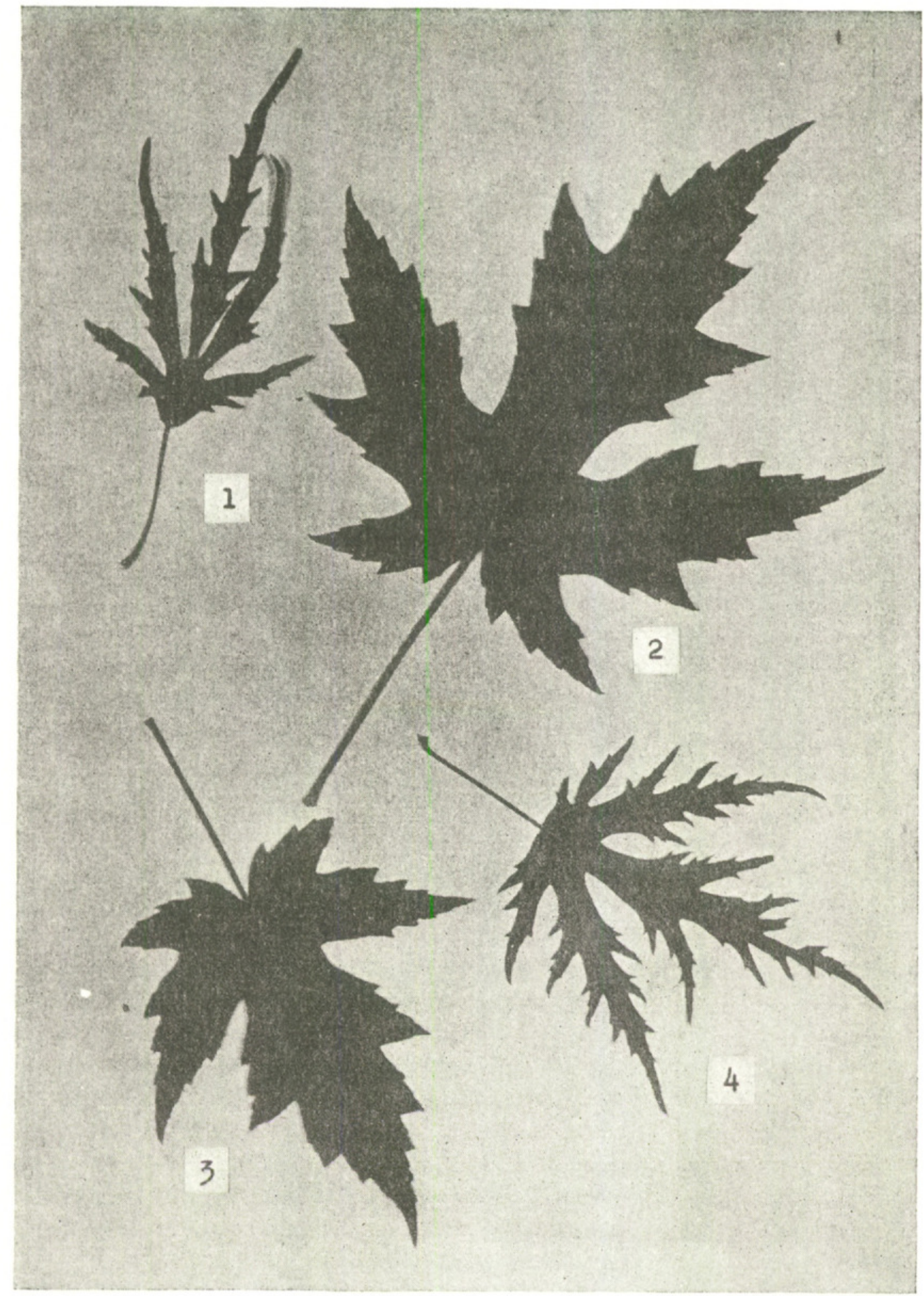

Pauley and Johnson, Aberrant Silver Maples 


\section{$2 \mathrm{BHL}$ Biodiversity Heritage Library}

Pauley, Scott S and Johnson, Albert. 1952. "Aberrant Silver Maples." Journal of the Arnold Arboretum 33(3), 296-298. https://doi.org/10.5962/p.185814.

View This Item Online: https://www.biodiversitylibrary.org/item/33609

DOI: https://doi.org/10.5962/p.185814

Permalink: https://www.biodiversitylibrary.org/partpdf/185814

\section{Holding Institution}

Missouri Botanical Garden, Peter H. Raven Library

\section{Sponsored by}

Missouri Botanical Garden

\section{Copyright \& Reuse}

Copyright Status: In copyright. Digitized with the permission of the rights holder.

Rights Holder: Arnold Arboretum of Harvard University

License: http://creativecommons.org/licenses/by-nc-sa/3.0/

Rights: https://biodiversitylibrary.org/permissions

This document was created from content at the Biodiversity Heritage Library, the world's largest open access digital library for biodiversity literature and archives. Visit BHL at https://www.biodiversitylibrary.org. 